\title{
On brackets in translation (or how to elaborate in brackets)
}

\author{
Magnus Levin, Jenny Ström Herold \\ Linnaeus University (Sweden)
}

\begin{abstract}
This paper presents findings on the use of brackets in original texts and translations based on the Linnaeus University English-German-Swedish corpus (LEGS). The results show that in originals, brackets are the most frequent in English and the least in Swedish. Translations usually contain more brackets than originals. There are two reasons for this. First, most brackets are retained, and secondly, many are added. Added brackets mostly contain short synonyms facilitating target-reader comprehension. English translators introduce the most changes (additions, omissions, downgrades and upgrades), and Swedish ones the least. Brackets tend to fulfil content-oriented rather than interpersonal functions. When brackets are replaced by other punctuations marks in translations, these tend to be commas or no punctuation marks at all. German originals have a stronger preference for bracketing phrases than clauses compared to English and Swedish. These German phrasal brackets are often expanded into clauses in translations.
\end{abstract}

Keywords: brackets, punctuation, LEGS, explicitation, translation strategies, clause building, English/German/Swedish

\section{Introduction}

Writers of non-fiction are faced with the complex task of conveying complex states of affairs, while simultaneously avoiding making their texts too long. Translators, in turn, often feel the need to make their texts slightly more elaborate to target-text readers by, for instance, adding information on cultural features that are less known in the target culture. Brackets enable the insertion of more or less information-dense additions and would therefore seem to be suitable structures to use for such elaborations. Illustrative examples of bracket usage in an English original and its German translation are given in (1), involving the retention, addition and omission of information:

(1) During the Miocene period (23-5.3 million years BP), the equines diversified and took on the appearance of modern species. The modern survivors of the equines, which include horses, donkeys, asses, zebras, kiangs and onagers, evolved during the Pleistocene period (2.5 million-12,000 years $B P$ ) alongside our own human ancestors ( see the next entry for a more detailed discussion of the early equids). [LEGS; English original]

CROSSING THE BORDERS: ANALYSING COMPLEX CONTRASTIVE DATA. Edited by Anna Čermáková, Signe Oksefjell Ebeling, Magnus Levin and Jenny Ström Herold. BeLLS Vol 11, No 1 (2021), DOI: 10.15845/bells.v11i1.3441. Copyright $(9)$ by the author. Open Access publication under the terms of CC-BY-NC-4.0. 
Im Lauf des Miozäns (vor 23-5,3 Mio. Jahren) diversifizierten sich die Pferde und ähnelten im Aussehen bereits den heutigen Arten. Die modernen Vertreter der Pferde (Gattung Equus), zu denen Pferde, Esel, Zebras, Tibet-Wildesel und Halbesel gehören, entwickelten sich während des Pleistozäns (vor 2,5 Mio.-12 000 Jahren), gleichzeitig mit den Vorfahren des modernen Menschen Ø. [German translation]

Both the original and the German translation contain three pairs of brackets, but these only partly match each other. The years for the two time periods are transferred directly, while the German translator once adds a term in brackets where the original makes do with only one (i.e., equines > Pferde (Gattung Equus) ['horses (genus equus)']). Finally, the English signpost (see the next entry ...) is omitted in the German version, suggesting that German writing sometimes may prefer a less reader-oriented style than English, a hypothesis that will be explored further in this paper.

In the following, we explore both distributions and uses of (round) brackets in English, German and Swedish original and translated popular non-fiction while addressing the following research questions:

- How frequent are brackets in English, German and Swedish originals and translations?

- What functions do brackets serve and what syntactic forms does bracketed text have in originals and translations?

- How are brackets rendered in translations in terms of being, e.g., retained, added or omitted, and what other punctuation marks are used as correspondences?

- To what extent do translations adhere to the target-language norms and/or to what extent does source-text usage "shine through" in translations?

As for the structure of this paper, Section 2 presents the LEGS corpus material and how we went about in the search process. Section 3 gives an overview of the previous studies on punctuation. Section 4 starts by presenting the findings for the originals and then moves on to the patterns observed in translations.

\section{Material and method}

This study is based on material from the Linnaeus University English-German-Swedish corpus (LEGS) (Ström Herold and Levin, 2019) which includes recently published (2000s) non-fiction books in English, German and Swedish. It is balanced for all three languages and for each original we always include target texts in the other two languages. The corpus covers both narrative and instructive genres, such as biographies, popular science and self-help books. To avoid author- or translator-specific features, each author and translator is represented only once.

The trilingual structure of the LEGS corpus is illustrated in Figure 1: 


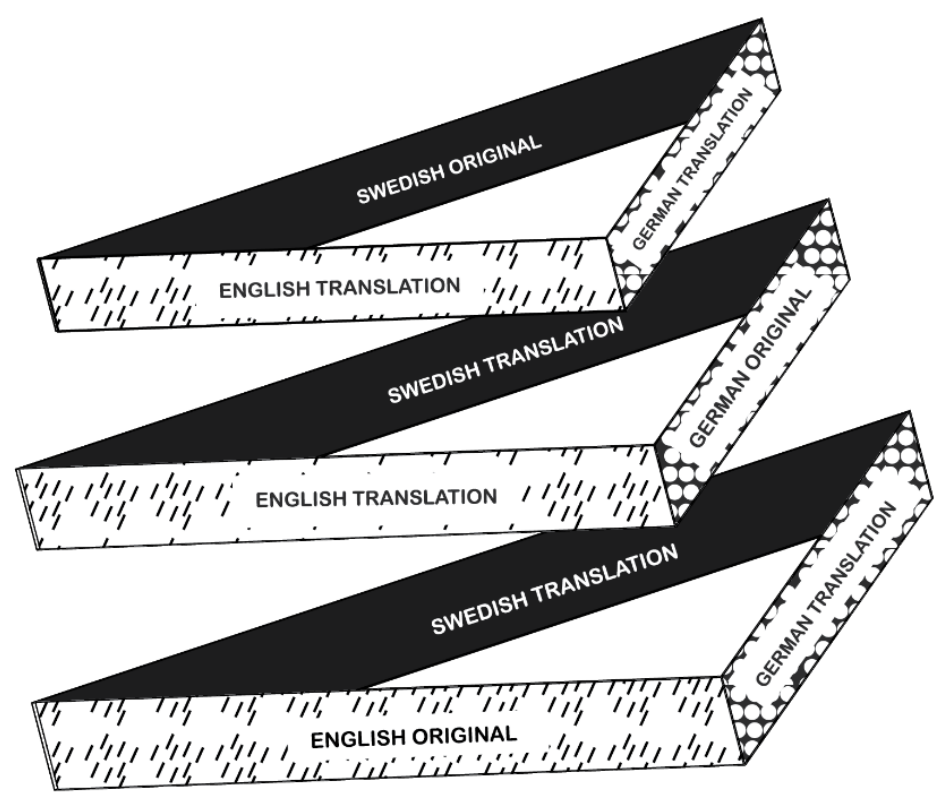

Figure 1. The structure of the Linnaeus University English-German-Swedish corpus (LEGS).

The present study covers a selection of the LEGS corpus, i.e. eight English, eight German and eight Swedish texts with two translations for each text. Some of the texts in the corpus were excluded because they would severely skew the findings. For example, cookbooks were removed due to their extreme use of brackets for measurement conversions both in originals and translations (e.g., $150 \mathrm{~g}(1 \mathrm{l} / 2 \mathrm{dl})$ strösocker $(\mathrm{Sw}$.) $>2 / 3$ cup $(5 \mathrm{oz} / 155 \mathrm{~g})$ sugar $)$. The bracket usage in this special genre warrants further studies, but the sheer numbers - more tokens in a single text than in a whole subcorpus - would turn this into a study of brackets in cookbooks. ${ }^{1}$ The approximate word counts for each subcorpus in the present study are given in Table 1.

Table 1. Word counts for the LEGS subcorpora included in the present study.

\begin{tabular}{|l|c|c|c|c|}
\hline & & $\begin{array}{c}\text { English } \\
\text { translation }\end{array}$ & $\begin{array}{c}\text { German } \\
\text { translation }\end{array}$ & $\begin{array}{c}\text { Swedish } \\
\text { translation }\end{array}$ \\
\hline English originals & 434,000 & $*$ & 416,000 & 421,000 \\
\hline German originals & 329,000 & 374,000 & $*$ & 337,000 \\
\hline Swedish originals & 335,000 & 353,000 & 331,000 & $*$ \\
\hline
\end{tabular}

The table shows some perhaps peculiar differences in word counts. However, these can, at least to some extent, be explained by structural or cultural differences between the languages. For instance, German and Swedish use solid compounds (or compounds with hyphens) while English usually writes noun modifiers separate from their head nouns (e.g., Rolex watches > Rolex-Uhren (Ge.); Rolexklockor (Sw.); see Ström Herold and Levin, 2019), which means that the word count will increase in languages where juxtaposition is prevalent. Culturally motivated additions or omissions, sometimes of whole sections, is an additional factor.

It should be noted that the books available in each source language affect the selection of texts included in the corpus. Not only are the books translated from German and Swedish shorter than those translated from English, more German and Swedish books also tend to belong to more reader-oriented genres, such as instructive self-help books. As will be seen below, the greater proportions of such interpersonal texts in these languages have some bearing on the results.

\footnotetext{
${ }^{1}$ Another Swedish original text was discarded because the English translator transformed 600 endnotes, mostly containing references, into brackets in the running text.
} 
For our search we used a custom-made LEGS interface and included all round brackets in originals aligned with their corresponding translation segments in the two target languages. We also searched for all round brackets in translations having a "non-bracket" in the original. In all, this procedure retrieved 5923 bracket pairs in either originals or translations as well as 1987 non-bracketed correspondences. ${ }^{2}$ We manually checked both originals and translations to ascertain that the extensive use of footnotes or endnotes would not affect the findings. The source-text and target-text instances were classified according to their functional and formal features and, for target texts, the translation strategies that were applied. The approach in the present study thus exploits the two main advantages of using translation corpora rather than monolingual reference corpora when comparing languages as argued by Nádvorníková (2020: 46): first, it allows comparisons between frequencies in originals and translations, which can be considered to be equivalent texts, and second, it enables the analysis of translation strategies and the punctuation systems of different languages.

The following section provides an overview of previous work on brackets and related punctuation marks such as commas and dashes. In general, comparative or translation-based studies on punctuation use in different languages are rare, which also applies to brackets. Nevertheless, some important translation trends have been noted that will be explored further in this study.

\section{Brackets in monolingual and contrastive studies}

According to Leech et al. (2009: 246) brackets (both round and square) "have increased immensely" in English and are typical for a more "serious written style" (cf. also Crystal, 2015: 157). Similarly, Biber and Gray (2016: 120) remark on their frequent use in academic prose, more specifically as information-dense juxtaposed appositions - NP (NP) - as in International Meta-analysis of mortality Impact of Systemic Sclerosis (IMMISS), where the acronym is introduced in brackets. In this example, the spelt-out term and the bracketed acronym are coreferential, which, as suggested by Biber and Gray (2016: 205-206), was also how brackets were used originally in English. Nowadays, brackets may encompass all sorts of information. Biber and Gray (2015: 205) show that these may include descriptive specifications or more "distant" information and that the bracketed text can be relatively lengthy and complex, yet nominally dense, as in their example: Numerous variables were measured, including [...] date of enrollment (date of first visit to the cohort with the pertinent diagnosis), age at first visit [...]. In a similar vein, Bredel (2018: 11) refers to brackets as "communicative marks". By using brackets, authors make themselves visible in their text (cf. also Baumgarten et al., 2008: 188), by illustrating or explaining previous information to the reader: Sie saßen (es war Winter geworden) in der Stube ['They sat (it had turned winter) in the living room] (Bredel, 2018: 12). Here, the brackets include a complete sentence which, parenthetically, supplies the background information that the author deemed necessary for the interpretation. It should be noted that brackets are considered optimal candidates for parenthetical inserts (parentheses), appearing medially, but that they may also appear finally in a sentence (Quirk et al., 1985: 1625).

In monolingual studies and reference books on punctuation, brackets are sometimes contrasted with other 'correlative' punctuation marks (Quirk et al., 1985: 1625-1631), i.e., punctuation pairs. In these sources, either their interchangeability is highlighted or differences

\footnotetext{
${ }^{2}$ In contrast to Baumgarten et al. (2008), we did not include square brackets in our searches, but among our included tokens are some instances of such brackets occurring as correspondences of round brackets. For instance, a German author marking an omission in a quote with round brackets (...) was rendered by the English translator in square brackets $[\ldots]$. The few hundred remaining square brackets are not likely to have affected the results decisively.
} 
in terms of style and semantics. For instance, the German Duden ( $\operatorname{RgD}, 2016: 517)$ suggests that parenthetical inserts can be placed between either brackets, commas or dashes, without any stylistic or semantic implications. Bredel (2018: 12-13), on the other hand, suggests that the choice of punctuation marks has semantic bearing. Returning to the example above, replacing the brackets with commas would yield a slightly different interpretation or focus: Sie saßen, es war Winter geworden, in der Stube. According to Bredel, the commas would emphasise the "syntactic disintegration" of the parenthesis, which is claimed to be different from the more communicatively used brackets. Comparing brackets and commas, the English Style Guide (2016/2019: 12), used by the European Commission, writes that brackets are used much like commas, except that a bracketed text segment, compared to an insert between commas, has "a lower emphasis", i.e., is more strongly backgrounded. From a stylistic perspective, dashes are usually said to have a more informal, dramatic flair than brackets and commas (Quirk et al., 1985: 1629; Leech et al., 2009: 245; Crystal, 2015: 158).

As noted above, brackets, and punctuation marks in general, have gone much unnoticed in translation studies, which is surprising considering that the appropriate use of punctuation marks is not a trivial matter for translation students or professional translators (cf. Ingo, 2007: 67; Shiyab, 2017: 93-101). However, the last few decades have seen a growing interest among translation scholars with studies on the translational rendition of different punctuation marks (Bystrova-McIntyre, 2007: 137-138; Baumgarten et al., 2008; Englund Dimitrova, 2014; Wollin, 2018; Frankenberg-Garcia, 2019; Ström Herold and Levin, forthcoming). Still, many of these studies have rather strong limitations, often based on small data sets (if any) with some rare exceptions. Based on these previous studies, it is possible to tease apart three typical translation tendencies for punctuation marks. One is direct transfer, as the most common translation strategy, often reaching about 90\% (Gustafsson, 2013; Wollin, 2018; FrankenbergGarcia, 2019; Ström Herold and Levin, forthcoming). The second one is normalization/standardisation, where an exaggerated use of punctuation marks used as a stylistic device tends to be toned down in the translation (Englund Dimitrova, 2014: 96). Finally, there is a tendency for explicitation, i.e. the inclination to spell things out rather than leave them implicit (Baker, 1996: 180). Explicitation is often cited as a Translation Universal, i.e., a feature occurring in translations rather than originals, and that is not the result of sourcetext interference (Baker, 1993: 243). In the context of punctuation marks, explicitation may be reflected in the replacement of a punctuation mark by lexical material (e.g., a colon being replaced by a connector, as argued by Eskesen and Fuglsang (1998)). Explicitation has also been approached from the perspective of brackets. Baumgarten et al. (2008: 190) even suggest that brackets are "typical sites of translational explicitation" as they are frequently used by translators to add information that is not present in the originals.

To our knowledge, Baumgarten et al.'s study (2008) is the only corpus study of the use of round and square brackets in originals and translations. Their material includes English originals and their German translations, but also a comparable corpus with German originals, facilitating comparisons with 'translated German'. The texts stem from two different popular science magazines and, thus, their material is less varied than the material used in the present study, which includes various texts in the broader non-fiction genre. Their initial assumption was that German translations would contain more/added brackets as a result of translational explicitation, but also because their German control corpus contains more brackets than the English originals. Their results show that the German translations indeed contain very many added brackets (about 60\%), but also, surprisingly, that translators remove original brackets to a very high extent (about 70\%). Baumgarten et al. (2008: 191-192) conclude that most changes in the German translations are due to adaptation, where translators adapt to the textual conventions of the target language, and not translational explicitation. As for the function of the information included in brackets, their study suggests that English originals use brackets 
for subjective, writer-based elaborations to a much higher extent than the German originals (ibid. 2008: 200), see example (2):

(2) Subsequent work by Mundt, Bo Reipurth of the European Southern Observatory in Santiago, Chile, and others (including me) showed that ...

In contrast, German originals and translations tend to use them for reader-oriented, intertextual references and content-based brackets, e.g., for including specialized terminology and biographical or geographical information (ibid. 2008:20), as in (3): ... an der Universität Newcastle upon Tyne (England) ...

The next section will present the findings on brackets, in English, German and Swedish originals and translations. By combining comparable and translation data, our material allows us to draw conclusions about language norms and translation-related features.

\section{Results}

\subsection{Brackets in originals}

This section presents the frequencies of brackets in English, German and Swedish originals, the functions fulfilled by brackets in those texts, the distributions of the functions across originals and finally the syntactic forms of the bracketed text.

First, the quantitative overview in Figure 2 indicates significant frequency differences between the three source-text corpora, using a log likelihood test:

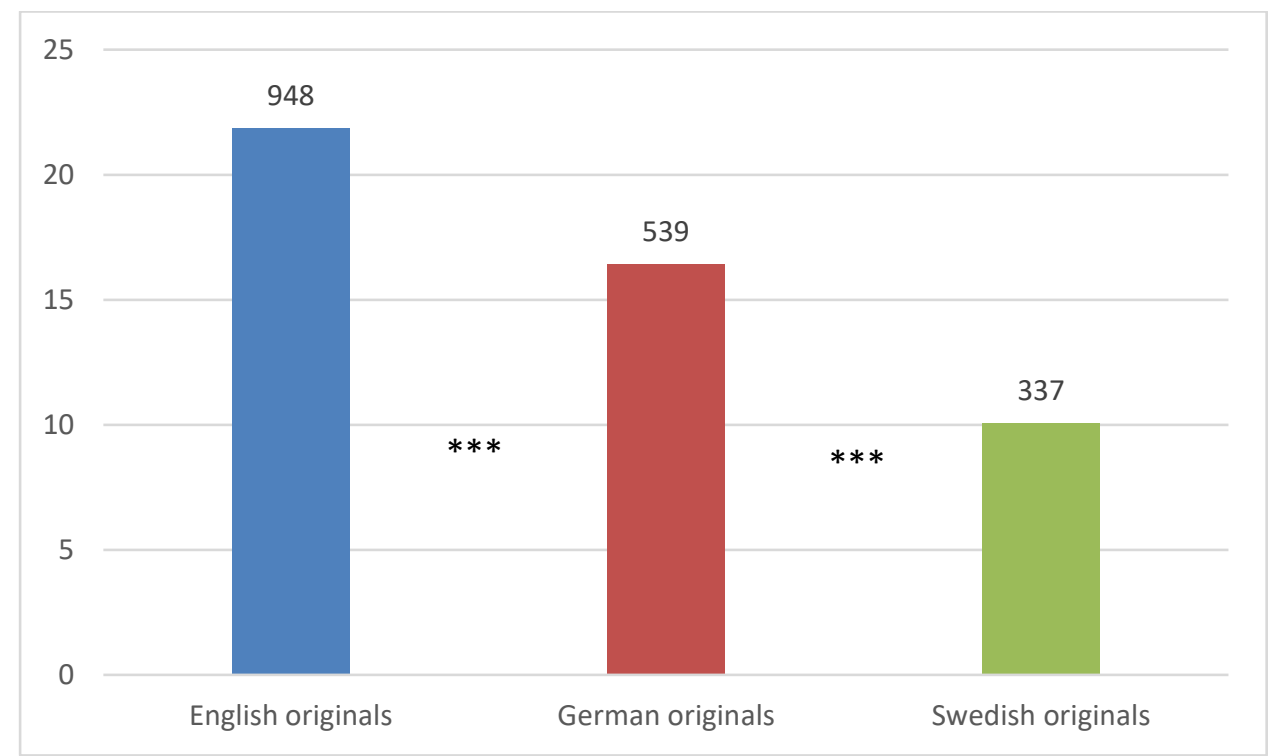

Figure 2. Brackets in English, German and Swedish originals in LEGS per 10,000 words.

The findings seem quite solid with brackets being the most frequent in English originals and the least frequent in Swedish originals. A point illustrating this is that of the seven texts producing more than twenty brackets per 10,000 words, five are English, two German and none Swedish. The two texts with the highest frequencies for German are the two most clearly operative texts (such as a self-help book for cat owners), which suggests that more instructive, reader-oriented genres contain more brackets than more content-oriented genres, such as biographies. The investigated English texts do not include instructive texts, but still yield the highest number of brackets. Further studies of genre-specific uses of brackets are called for to 
determine possible differences between more instructive genres and what Leech et al. (2009: 245) refer to as more "serious written style".

In the material, we identified two main functional categories, content-oriented brackets and interpersonal brackets, with two subcategories for the former and three for the latter. As the terms imply, content-oriented brackets focus on adding to the content of the text, while interpersonal ones are more reader- or author-oriented and as such may be considered a prototypical case of using brackets as communicative marks (Bredel, 2018: 11). Our labels for the functional categories have been inspired by House's (e.g., 1997, 2011) seminal work on communicative styles in English and German, establishing a cline between the languages with English writing generally being more interpersonal, whereas German is more content-oriented. Interpersonal style is characterized by features such as author presence and reader address, while content-oriented style relies more heavily on transmission of facts.

In the following, the functional subcategories will be presented, starting with the contentoriented synonym and specification, and then the interpersonal reader address, hedge and subjective author comment. Figure 3 presents a graphic overview of the categories and subcategories.

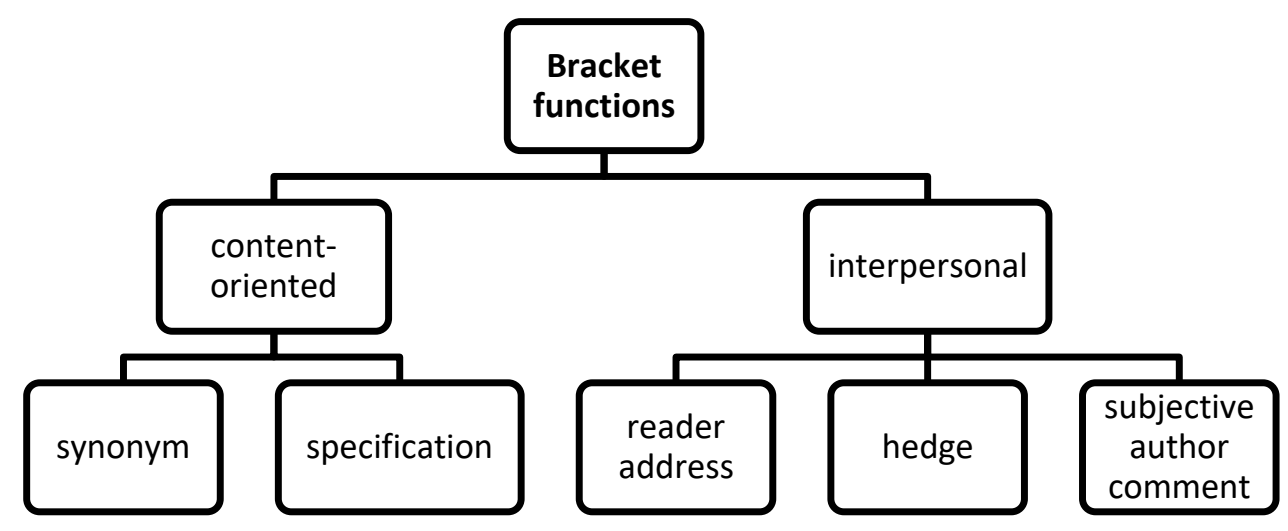

Figure 3. Functional categories of brackets in the LEGS material.

The subcategory synonym relates to the original bracket function proposed by Biber and Gray (2016: 205-206) above. Here, the bracketed text is co-referential with some item outside the brackets. Typical instances involve the addition of name variants (4), measurements using different systems (5), and the introduction of acronyms (6). The second subcategory of contentoriented brackets, i.e., specification, involves the addition of factual details to the nonbracketed text, as exemplified in (7) and (8).

\section{I.I Content-oriented: Synonym}

(4) On 3 September at Bydgoszcz (Bromberg), random firing against Poles in the streets led to a massacre ... [LEGS; English original]

(5) They undulate their whole body to propel themselves through the water and can reach speeds of $38 \mathrm{~km} / \mathrm{h}$ (24 $\mathrm{mph}$ ). [LEGS; English original]

(6) The trap was given a name by Dwight Eisenhower in his farewell speech as President on January 17, 1961: the military-industrial complex (MIC). [LEGS; English original] 


\section{I.II Content-oriented: Specification}

(7) Imperial Oil (of which Exxon owns a majority share) sank about $\$ 13$ billion ... [LEGS; English original]

(8) During the Byzantine period (4th-15th c.), the elite preferred expensive silks and linen to woolen garments. [LEGS; English original]

Among the interpersonal brackets, the subcategory of reader address covers instances where the reader is addressed "outside the text", as in (9), and metatextual comments guiding the readers, as in (10). The subcategory of hedges is in some ways categorically ambiguous as hedges may serve slightly different functions. On the one hand, they may refer to the truth value of the content and thus would group with the content-oriented brackets, but on the other hand, they maintain relations with readers, which is why we classified them as interpersonal brackets. This also agrees with Hyland who finds that hedges are often ambiguous and rarely allow just one single interpretation (1996: 437, 439; cited in Kranich, 2011: 82). Thus, example (11) leans more towards a content-oriented interpretation, while (12) is more evidently subjective and reader-oriented in nature. Finally, there are instances where authors subjectively comment on or evaluate facts and events. This is exemplified in (13) and (14) where the subjective stance is highlighted by the adjectives striking and tantalizing. The examples given also illustrate the different available positions of bracketed texts - most occur sentencemedially, as in (11) - (13), followed by sentence-final position, as in (10), while the rarest is independent sentences, as in (14). ${ }^{3}$

\section{II.I Interpersonal: Reader address}

(9) ... while the bees are visiting your bee-friendly plants (if you haven't got any, I hope you'll plant some next spring) ... [LEGS; English original]

(10) The weaknesses of the program have also been hotly debated, particularly the question of whether the decision to phase out nuclear energy has led to a resurgence of coal (more on that next chapter). [LEGS; English original]

\section{II.II Interpersonal: Hedge}

(11) Whether the tests on which the participants improved measure perceptual ability, perceptual speed, or (as the authors interpret it) stimulus-driven attention is a moot point. [LEGS; English translation from Swedish]

(12) Despite his arrogance (or perhaps because of it) he was able to charm Atari's boss. [LEGS; English original]

\section{II.III Interpersonal: Subjective author comment}

(13) Andrew (who bears a striking resemblance to Baldrick from Blackadder) came up with the cunning plan ... [LEGS; English original]

(14) Mists and fogs [...] forced Hitler to accept that the Luftwaffe could not provide the vital support needed for his November target date. (It is tantalizing to speculate how differently things might have turned out if Hitler had launched his attack then rather than six months later.) [LEGS; English original]

The distributions of functions in originals are given below in Figures 4 and 5. Figure 4 shows the proportions and raw numbers of the two main functional categories, content-oriented and

\footnotetext{
${ }^{3}$ German has the strongest preference for medial position (74\%; English 67\%; Swedish 63\%), and Swedish for both final position (31\%; English 28\%; German 23\%) and independent sentences (6\%; English 5\%; German 3\%).
} 
interpersonal brackets, and Figure 5 presents the frequencies per 10,000 words for the five subcategories. It should be noted that English originals are presented in the middle of Figure 4 to illustrate the statistical significance.

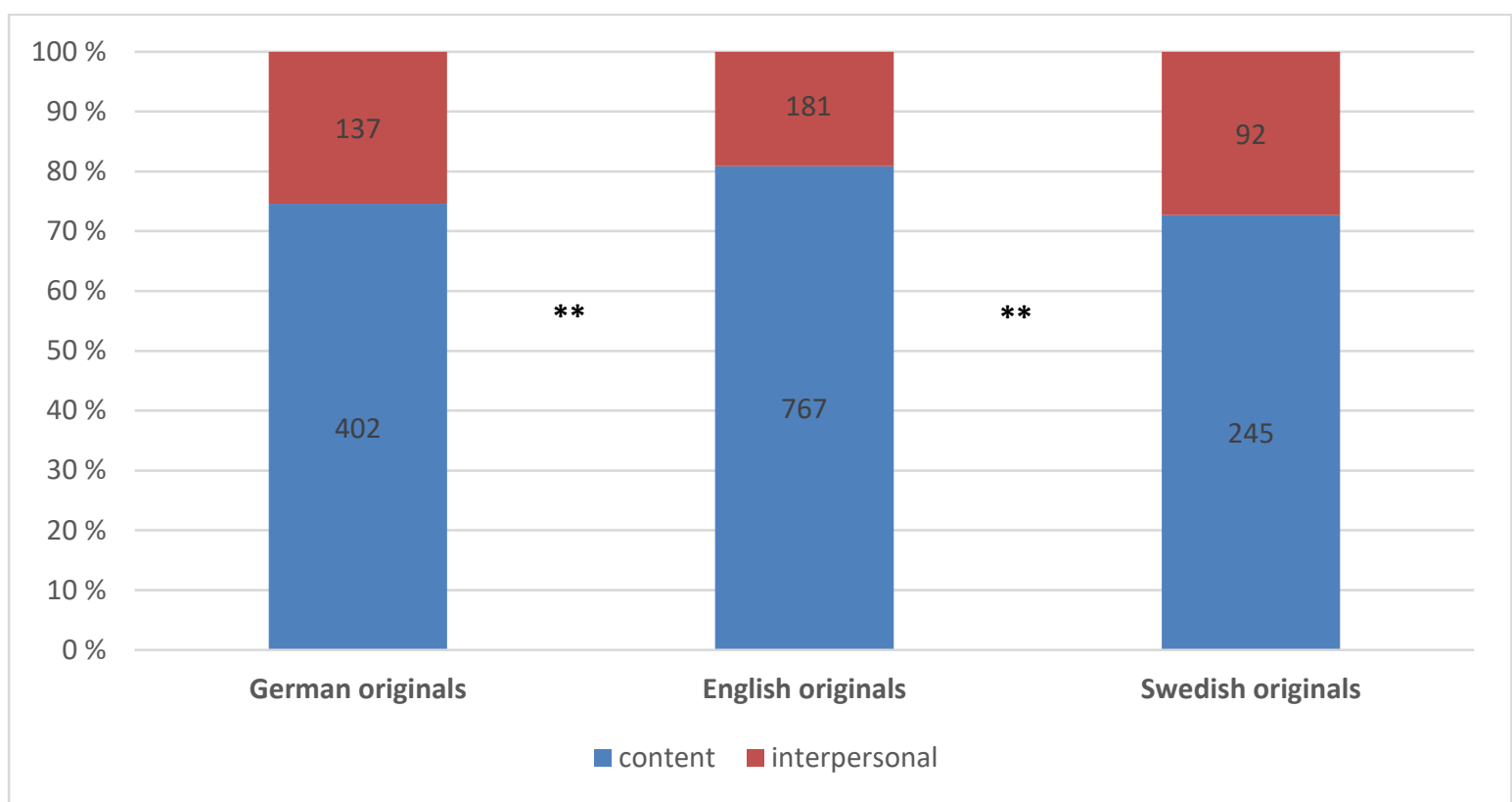

Figure 4. Proportions of main functions: content and interpersonal.

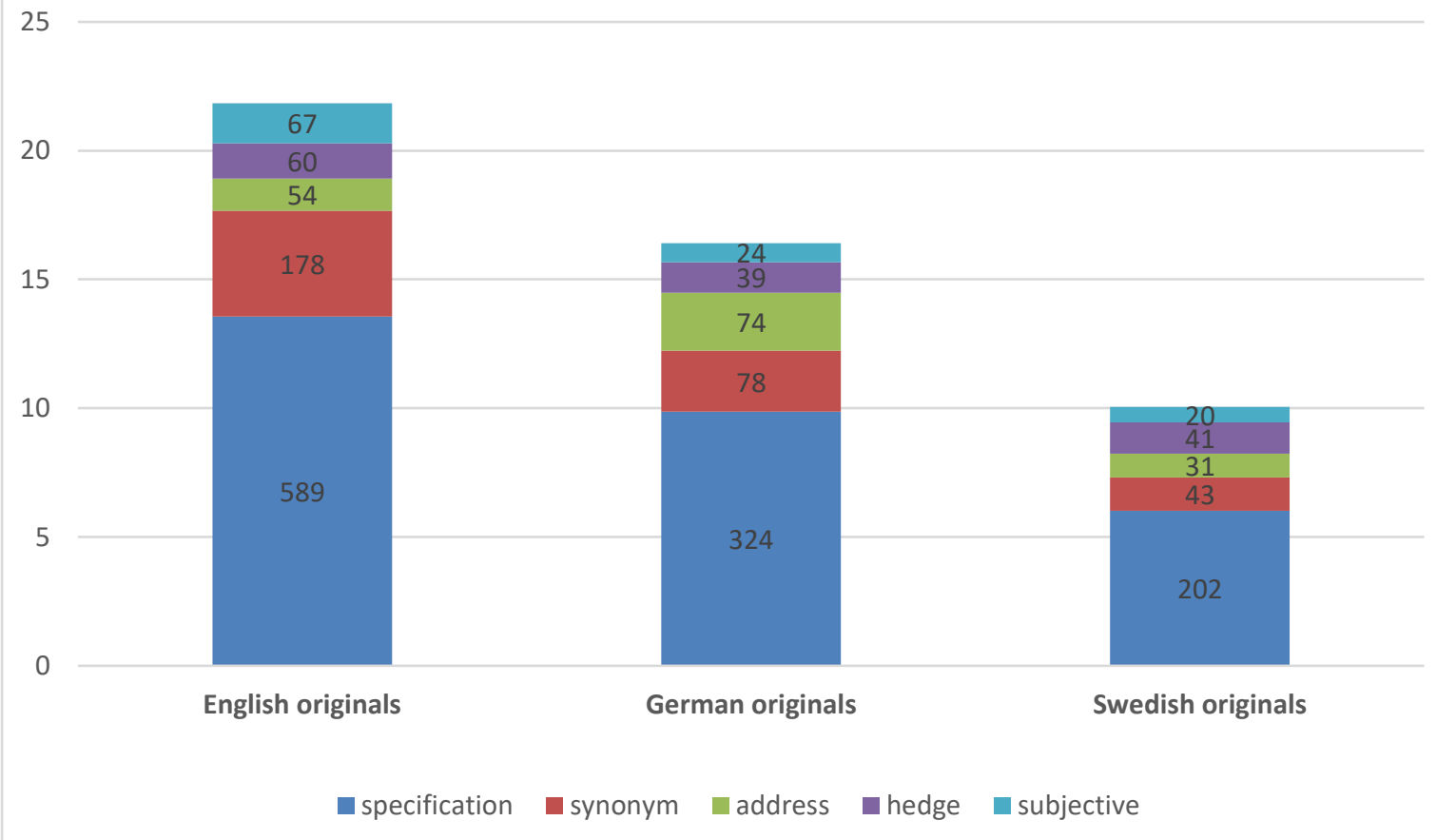

Figure 5. Subcategories of content and interpersonal functions per 10,000 words.

Figure 4 suggests that English original texts are more strongly associated with content-oriented brackets than German and Swedish. This was at least partly unexpected, seeing that Baumgarten et al.'s (2018: 191-192) findings on English and German indicate the opposite. In our data, the difference between English and the other languages should nevertheless not be 
overemphasized since the effect size is small. ${ }^{4}$ Moreover, the lower proportion of readeroriented genres represented in the English subcorpus in all likelihood promotes a larger proportion of content-oriented brackets in these originals. The functional subcategories in Figure 5 may therefore provide a more relevant picture. Here we see that the two contentoriented subcategories, specification and synonym, are indeed associated with English originals (though not very strongly so). ${ }^{5}$ Using signed deviations from expected cell-wise counts and their chi-squared contributions, we notice that English originals show particular dispreference for the address function. ${ }^{6}$ The most significant preference among the functional subcategories is for reader address in German and the second strongest for hedges in Swedish. ${ }^{7}$ Synonyms are somewhat more popular in English and somewhat less so in Swedish. ${ }^{8}$ The functions specification and subjective author comment are more or less equally preferred in the three languages.

Looking more closely at the observed differences between the subcategories, it is evident that one particular reason for the more frequent use of synonyms in English is the recurring use of synonymous measurements in this language, (as exemplified in (5)), a usage that is absent in the other languages. Moreover, the more frequent use of reader address in German is likely an influence of the German predilection for using intertextual signposts, as also noted by Baumgarten et al. (2008: 200) (e.g., (ab S. 42) translated into (see page 42 onward)). As for hedges, most Swedish instances occur in three books written by professors, which may indicate that bracketed hedges are a particular academic phenomenon carried over into the popular domain.

Apart from the functions of the bracketed texts, we decided to also take a closer look at the forms of the bracketed texts. This focus was inspired by some previously noted differences between the languages, one being the increasing German aversion to subordinate clauses, probably an avoidance strategy for difficult-to-process verb-final clauses (Becher, 2011; Bisiada, 2013; Ström Herold and Levin, 2018, forthcoming) and the other one being the overall German preference for nominal style (cf. Carlsson (2004) for German in contrast with Swedish). Therefore, all brackets were classified according to their syntactic form, either as i) clausal, i.e., instances which contain a verb phrase, or ii) phrasal, i.e., instances which correspond to a noun phrase or a prepositional phrase (examples of clausal brackets are given in, e.g., (7) and (9), and phrasal instances in (4) and (8)). Figure 6 presents the results from our originals:

\footnotetext{
${ }^{4}$ Independence of English vs Swedish and German collapsed, $\chi 2=12.58, \mathrm{df}=1, \mathrm{p}=* * *$; Cramer's V=0.08

${ }^{5}$ Using a cell-by-cell chi-square contributions; 0.32 for specification and 7.21 for synonyms.

${ }^{6}$ Deviation -28.6, cell-wise $\chi 2$ contribution is 9.92

${ }^{7}$ Deviations and cell-wise $\chi 2$ contributions are 27.01 and 15.53 , and 15.13 and 8.85 .

${ }^{8}$ Deviations and cell-wise $\chi 2$ contributions are 22.59 and 3.29, and -12.24 and 2.71 .
} 


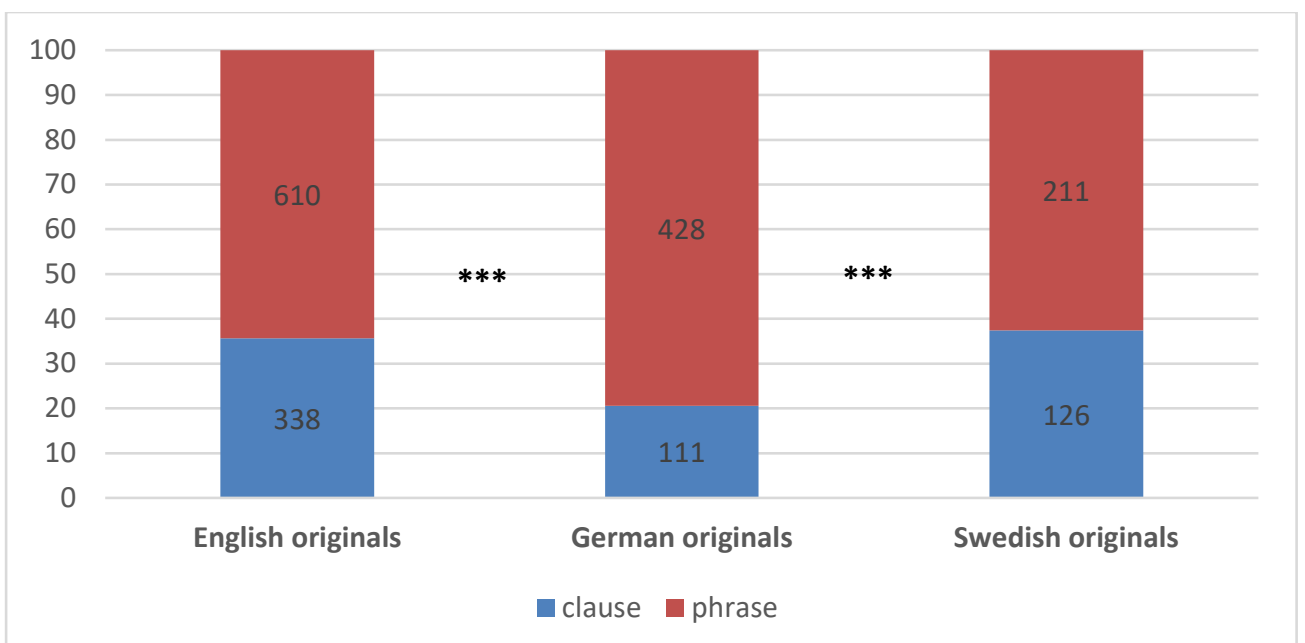

Figure 6. Proportions of clausal and phrasal brackets in English, German and Swedish originals.

The findings show that German originals put clauses in brackets significantly less than the English and Swedish ones. (For the frequencies of clauses and phrases in translations, see Section 4.2.4.). This result is in line with the above-mentioned contrastive studies suggesting that German prefers a more information-dense phrasal style and avoids subordinated clauses. This makes sense, as interpersonal functions such as addressing readers or adding author comments will require more elaborate structures than many content-oriented brackets which consist of, for example, one-word synonyms. Indeed, there is a positive correlation ${ }^{9}$ for all three languages between, on the one hand, clauses and interpersonal brackets and, on the other, phrases and content-oriented brackets.

A related observation concerns the number of words in the bracketed text. Phrases tend to be shorter than clauses and this is also reflected in the brackets in the LEGS material. As illustrated in Figure 7 below, English brackets contain more than 50\% more words on average than the German, with the Swedish originals in between.

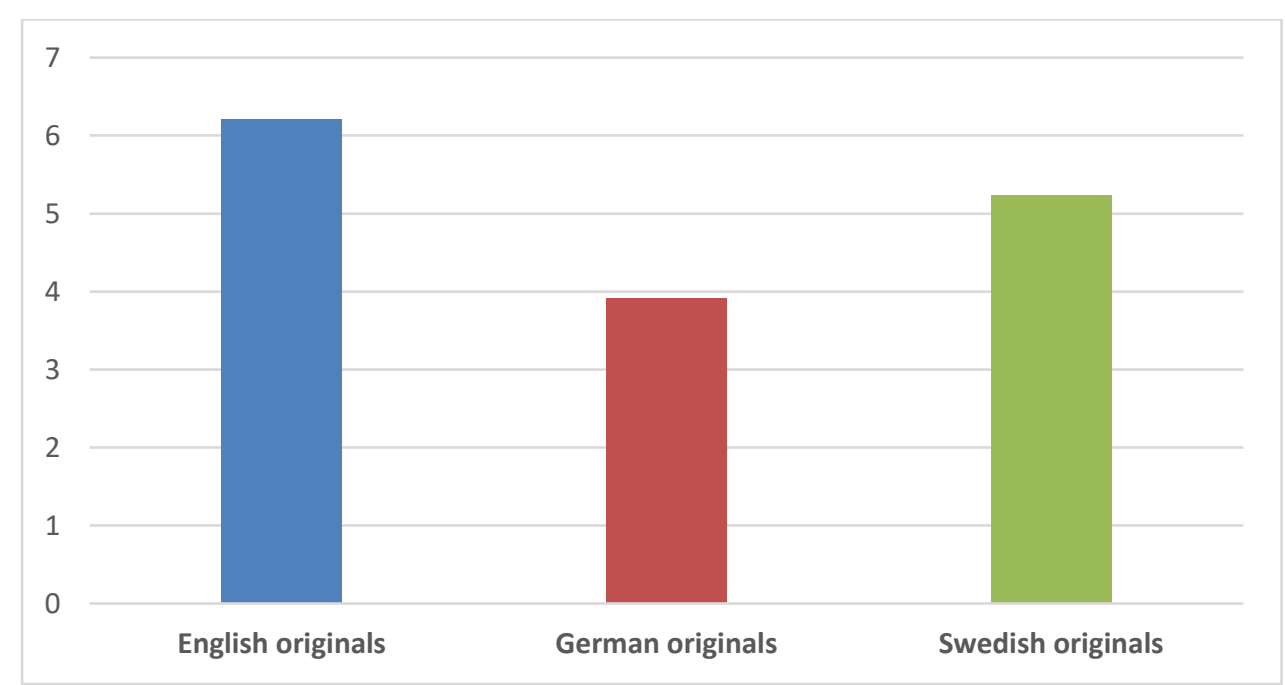

Figure 7. Average length in words of brackets in English, German and Swedish originals.

The lower proportion of clauses in German originals thus appears to be reflected in shorter brackets compared to English and Swedish. The different writing conventions in the three

\footnotetext{
${ }^{9}$ English $\chi 2=88.30, \mathrm{p}=<.0001 ;$ German $\chi 2=28.41, \mathrm{p}=<.0001 ;$ Swedish $\chi 2=41.86, \mathrm{p}=<.0001$
} 
languages, which were discussed in Section 2, probably affect these frequencies. We therefore compared the proportions of words occurring in brackets in the three subcorpora. This comparison indicates that English indeed differs from the other languages: 1.4\% of all English words appear in brackets, compared to only $0.6 \%$ in German and $0.5 \%$ in Swedish.

In this section, the findings from the LEGS originals have indicated that brackets are most common in original English and the least common in Swedish. The classification into functional categories suggests that most brackets are content-oriented, and that the unexpected difference between the subcorpora partly originates in content-oriented brackets being even more frequent in English than in the other languages and partly in slightly different compositions of the subcorpora. Furthermore, German texts have the strongest preference for phrasal constructions, a tendency also observed in previous studies (e.g., Carlsson, 2004; Becher, 2011; Ström Herold and Levin, forthcoming). Section 4.2 discusses the findings for the translations in LEGS.

\subsection{Brackets in translations}

\subsubsection{Congruent and non-congruent translations of brackets}

This section first presents the distributions of brackets in translations compared to originals, then the proportions of brackets retained in translations and finally the frequencies of the different non-congruent translation strategies. To begin with, Figure 8 presents the bracket frequencies in the three original corpora and the six translations in order to determine to what extent they differ.

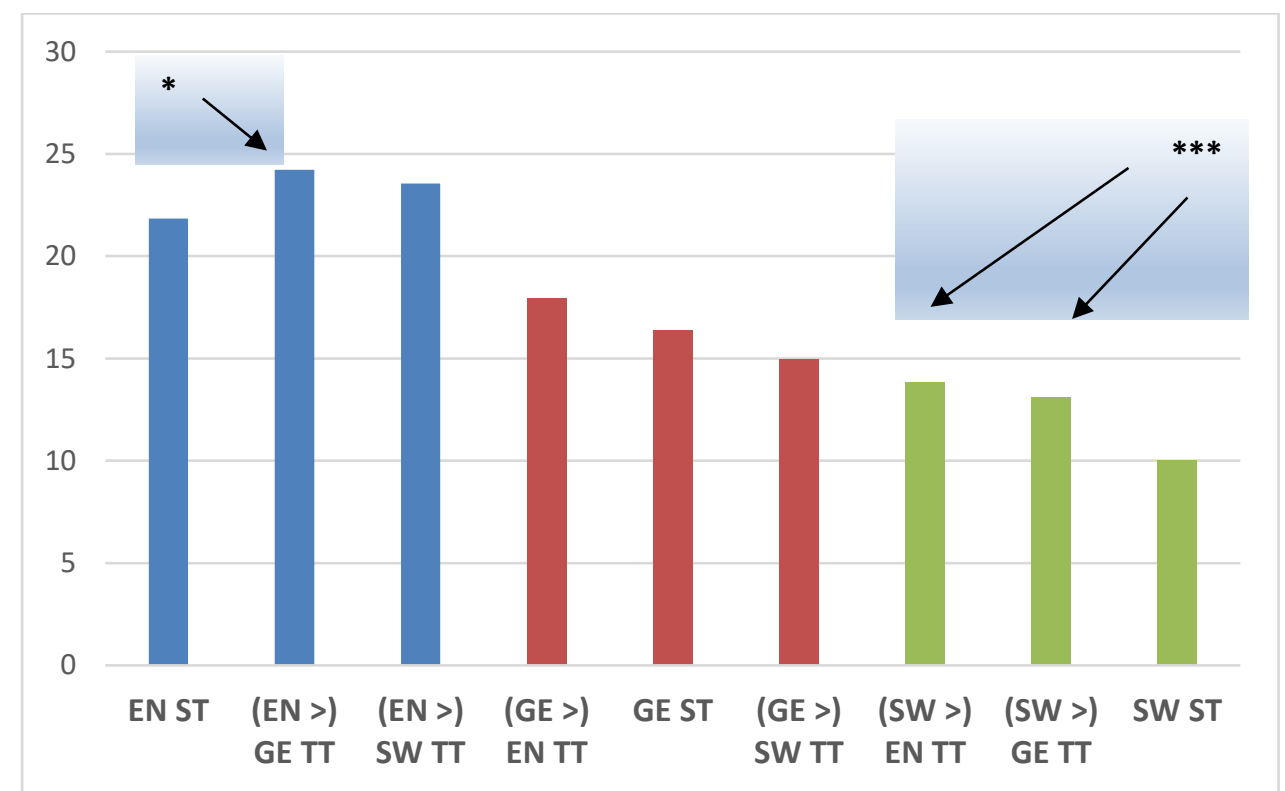

Figure 8. Frequencies per 10,000 words of brackets in originals and translations.

Two trends emerge, but they are difficult to disentangle: firstly, translations tend to contain more brackets than originals and, secondly, translations tend to approach target-language norms rather than adhere to source-text usage. For the first trend, five of six translation subcorpora contain more brackets than their originals (the exception being Swedish translations from German); while, for the second trend, four out of six translations "move towards" targetlanguage norms (the two translations from English originals do not follow this pattern). The three significant differences identified in Figure 8 all relate to higher bracket frequencies in translations. Two of these - the English and German translations from Swedish - produce the 
highest significance values. Notably, it is for these where the trends of using more brackets in translation and moving towards target-language norms strive in the same direction. ${ }^{10}$ For their English-to-German material, Baumgarten et al. (2008: 191-192) conclude that most changes in the German translations are due to adaptation, where translators adapt to the textual conventions of the target language, and not translational explicitation.

In the LEGS material, we identified five different translation strategies applied by the translators: brackets in originals can be I) retained in translations, II) they can be added, III) downgraded, IV) omitted or V) upgraded. The retention strategy simply means that the original brackets are kept in the translation (i.e. congruent translations) without substantial changes to the wording, as in (15) below. Added brackets refer to cases where the translator adds new information in brackets that is not available in the original. In (16), the imperial unit 311 ounces is added in the translation. In downgrades, a non-bracketed clause or phrase in the original is bracketed in the translation. This is exemplified in (17), where the original Swedish phrase appears between commas but is bracketed in the English translation. Omissions involve instances where the original brackets and the bracketed content are removed, as in (18). Finally, upgrades are the opposite of downgrades. In translation upgrades, the translators remove the brackets while keeping the content. Removing brackets may lead to zero punctuation or, as in (19), the use of another punctuation mark such as dashes.

\section{Retained}

(15) ... they were made even more homesick by the horrors of British cuisine, from overcooked mutton and cabbage to the ubiquitous custard (which also appalled the Free French). [LEGS; English original]

Ihr Heimweh wurde verstärkt durch die Schrecken der britischen Küche, von zerkochtem Lammfleisch mit Kohl bis zu der allgegenwärtigen Vanillesoße (die auch die Freien Franzosen abstoßend fanden). ("which also the Free French found repulsive') [German translation]

\section{Addition}

(16) Wir verlieren rund 100 Milliliter Flüssigkeit täglich. [LEGS; German original)] We lose around 311 ounces (100 milliliters) of fluid a day. [English translation]

\section{Downgrade}

(17) Ungefär tjugo kort, alltså tio par, blandas ... ('i.e. ten pairs') [(LEGS; Swedish original]

Twenty or so such cards (i.e., ten or so pairs) are shuffled ... [English translation]

\section{Omission}

(18) Was die drei Männer verbindet, ist ein Trugschluss: der Regression-zur-Mitte-Irrtum (englisch: regression toward the mean). [LEGS; German original]

What links the three men is a fallacy: the regression-to-mean delusion $\varnothing$. [English translation]

\section{Upgrade}

(19) ... wenn Ihr Kätzchen das (höchstwahrscheinlich) schon nicht tut. ('most likely') [LEGS; German original]

... even though your kitten is - most likely - not going to share that feeling. [English translation]

\footnotetext{
${ }^{10}$ Log likelihood English to German $p=<.05$; Swedish to English $p=<.0001$; Swedish to German $p=<.0001$
} 


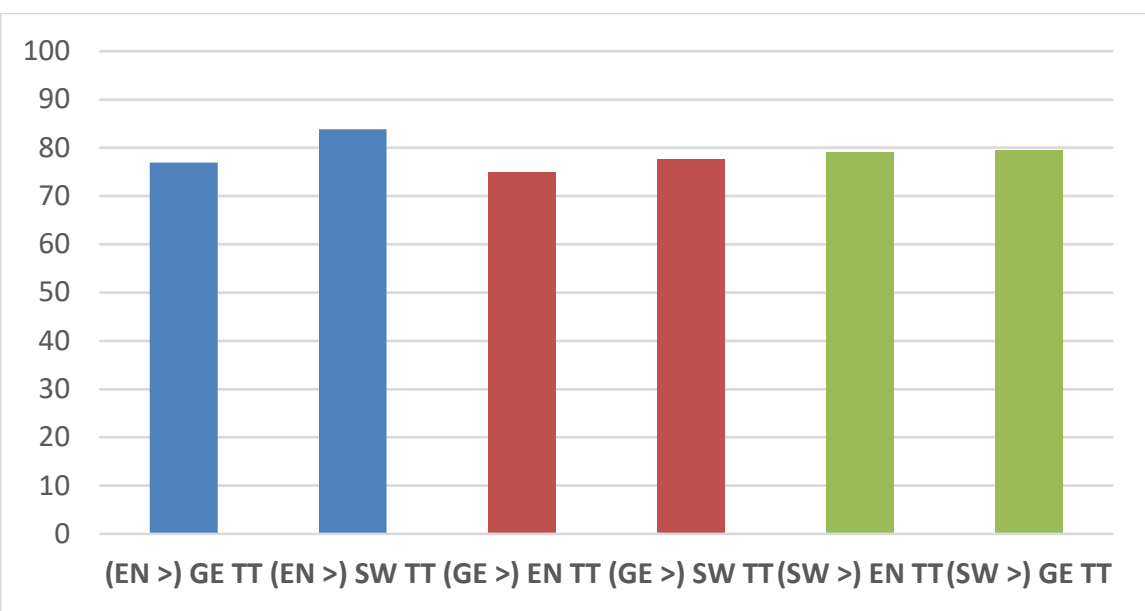

Figure 9. Proportions of retained brackets in translations.

Figure 9 presents the percentages of retained brackets in the translations. Two trends are evident in the LEGS data: Most brackets are retained in translations, and there are systematic target-language-specific preferences for the retention rates. The most obvious result is that a large majority of all brackets are directly transferred in the translations. In all six languages pairs, the retention rate reaches between $75 \%$ and $85 \%$. This confirms the strong tendency for direct transfer found previously for the translation of punctuation marks (Gustafsson, 2013; Wollin, 2018; Frankenberg-Garcia, 2019: 23; Ström Herold and Levin, forthcoming). These retention rates nevertheless stand in stark contrast to the low values presented by Baumgarten et al. (2008). In their study, only $30 \%$ of the brackets were directly transferred from English to German, a finding that is most likely due to specific genre-conventions in their narrowly sampled material. The second trend in our material is that pairwise comparisons between the target languages suggest that Swedish translators retain the most brackets and English translators the least. Figure 10 below sheds further light on this phenomenon by comparing the non-congruent translation strategies in the six target-text subcorpora. Of the translation strategies, additions are the most frequent for five of six translations (the only exception being the German-to-Swedish subcorpus).

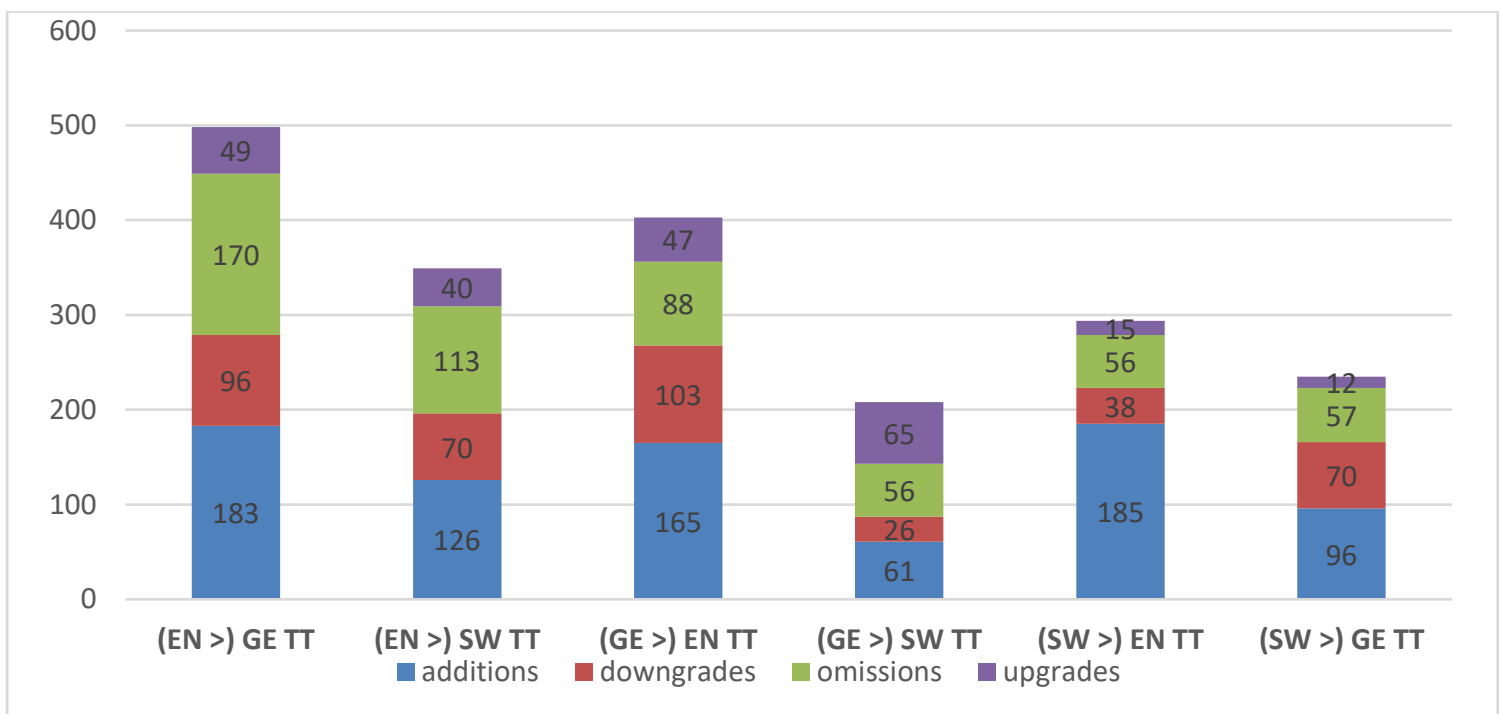

Figure 10. Raw numbers for non-congruent translation strategies per source language. 
The proportions of retained brackets in the six translations in Figure 9 are in a complementary relationship with those of the non-congruent translation strategies (additions, downgrades, omissions and upgrades) made in translations in Figure 10. English retains the least brackets, and also uses the most non-congruent strategies, while the language that retains the most brackets, Swedish, uses the least number of non-congruent strategies.

Pairwise comparisons between the target languages show that the non-congruent translation strategies are the mirror image of the retained brackets in Figure 9. Taken together, Figures 9 and 10 thus suggest that English translators retain the least and change the most brackets, Swedish translators retain the most and change the least with German translators consistently between these two. It is difficult to determine exactly why German translators seem more prone to changing punctuation than Swedish translators. One possible explanation is that Swedish, compared to German, is a minor language, and, thus, language-status-wise is lower on the hierarchy. This status difference between the languages is illustrated by the UNESCO's Index Translationum where English is the most frequent source language, German the third and Swedish the seventh. Another possible explanation, most likely connected to the afore-mentioned hierarchy, is that that the editors' briefs to the translators may differ depending on target language in that Swedish translators are given less options to interfere.

The next section explores the correlations between non-congruent translations and functional categories, the question being if there are any functions of brackets that are more commonly added or omitted, or otherwise altered in translations.

\subsubsection{Functional categories in non-congruent translations}

This section compares the frequencies of the five functional categories presented and exemplified in Section 4.1 (specification, synonym, reader address, hedge and subjective author comment) and the four non-congruent translation strategies (addition, omission, downgrade and upgrade). As seen in Figure 10, the LEGS data indicate that when translators introduce changes related to brackets, it is most likely to occur in connection with the addition of new information in order to make target texts more explicit to readers.

The 816 additions in the LEGS translations in Figure 11 present a homogenous picture of the distributions across the six language pairs:

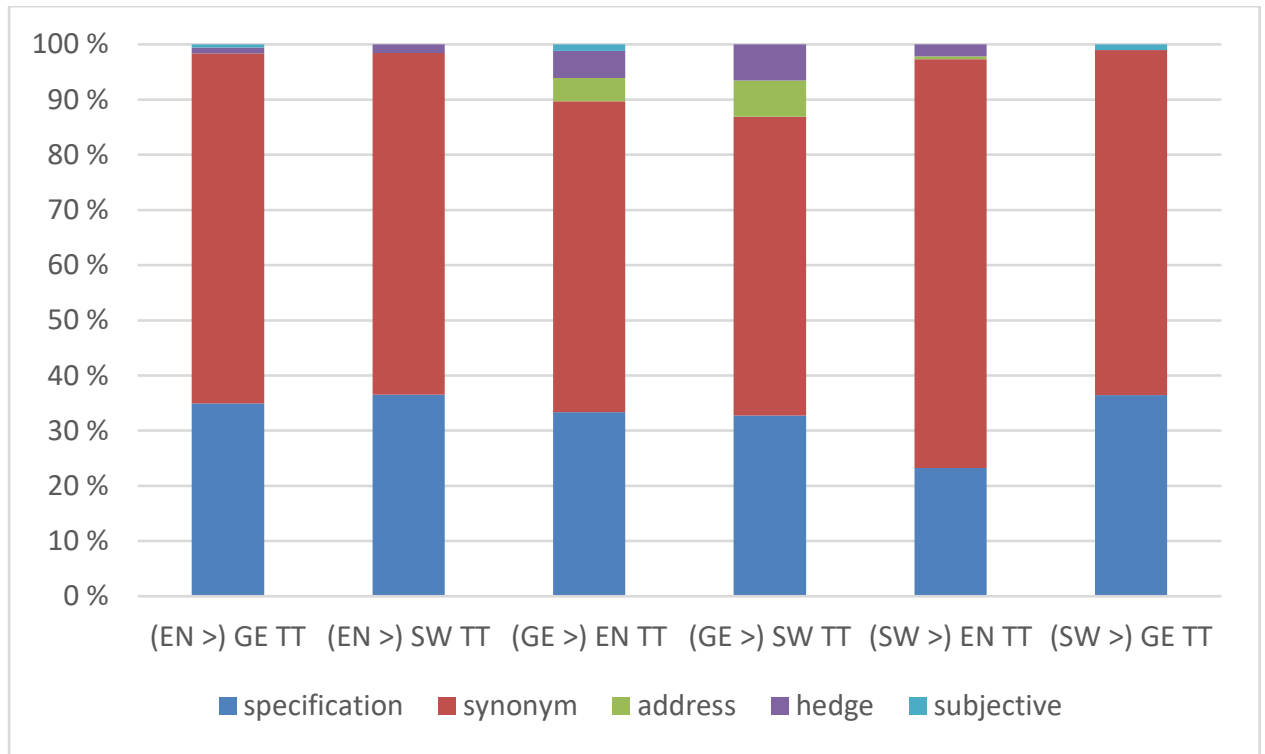

Figure 11. Functional categories of added brackets in translations. 
In the majority of cases, additions involve the introduction of synonyms, followed by specifications. Interpersonal brackets are added only rarely $(4.4 \%(36 / 816))$. These trends prevail in all subcorpora. Adding co-referential synonyms, which is also the original function proposed for bracketed text (Biber and Gray, 2016: 205-206), is an unobtrusive way for translators to make the target-text more comprehensible and explicit to the target-text readers. The added synonyms in translations fulfil similar functions to those found in originals. For example, acronyms that are less known in the target-language cultures are spelled out (the $R S P B>\operatorname{der} R S P B$ (Königliche Gesellschaft für Vogelschutz) (Ge.); RSPB (Kungliga fågelskyddssällskapet) (Sw.)), additional name variants are given (bei Klausenburg (Ge.) > near Kolozsvár (Cluj); vid Cluj (Klausenburg) (Sw.)) and sometimes phrases are also given in the target language (BP rebranded itself "Beyond Petroleum" > definierte BP sein Kürzel von „British Petroleum” in „Beyond Petroleum” (Jenseits von Erdöl) um (Ge.)). Added specifications mainly serve the purpose to explicitate various cultural phenomena that are not likely to be well known to target-text readers (Engelbrektsmarschen (Sw.) > the Engelbrekt March (named after the fifteenth-century rebel leader and proto-nationalist Engelbrekt Engelbrektsson)).

The second largest category of the non-congruent strategies, the 540 omissions, is more varied. As seen in Figure 12, the translations from English differ from those from German and Swedish:

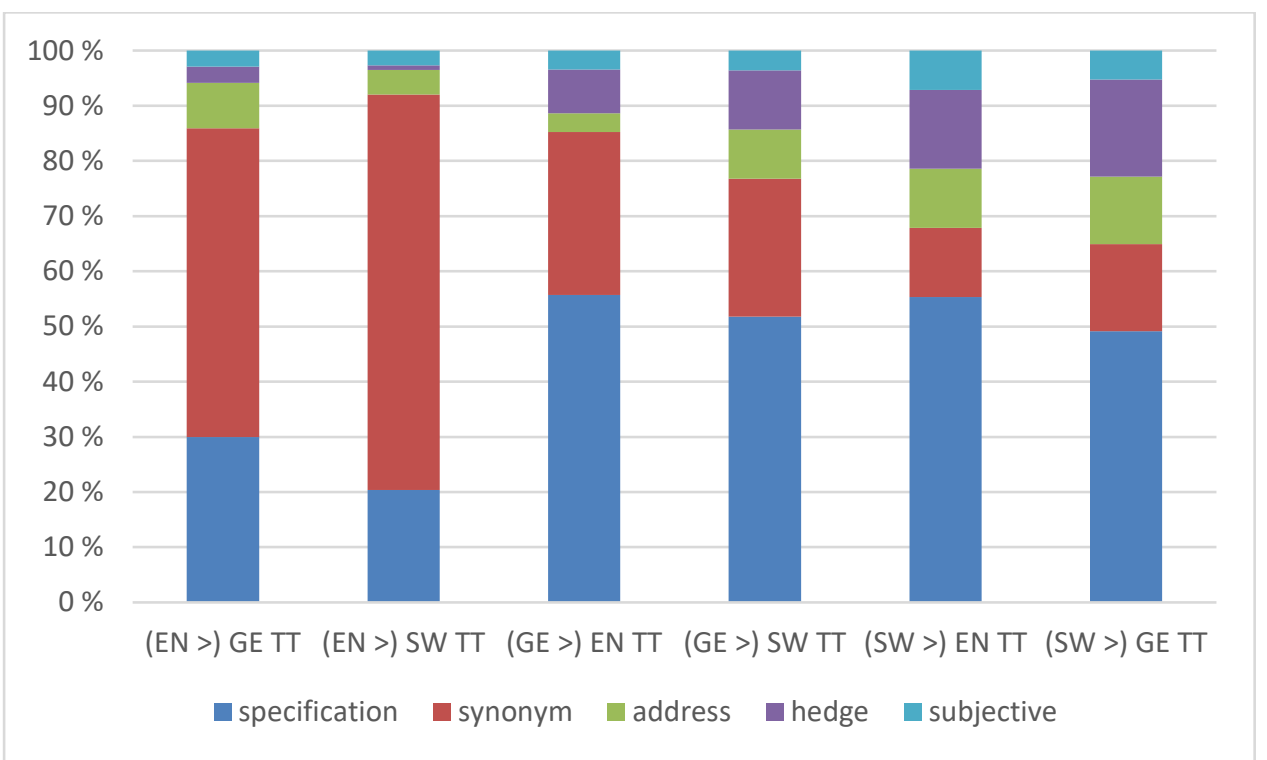

Figure 12. Functional categories of omitted brackets in translations.

The German and Swedish translations from English consistently omit the imperial units (e.g., three thousand meters (ten thousand feet) > 3000 Meter (Ge.); 3000 meter (Sw.)), which partly explains the high frequencies of omitted synonyms. Other instances of omitted synonyms relate to the source language, in contrast to the target language(s), sometimes using more than one term for a concept, e.g., a Greek or Latin term and a native term (Chlorophyll (Blattgrün) (Ge.) $>$ chlorofyll; klorofyll) or the source text itself containing a translation couplet that appears superfluous in the target text (With typical Nazi bombast [...] codenamed Adlerangriff (Eagle Attack) > erhielt [...] den bombastischen Codenamen „Adlerangriff“ (Ge.)). In some cases, translators omit bibliographical or historical data, as when the English Charles Darwin (180982 ) is rendered only as Charles Darwin in the German translation. Interestingly, Baumgarten et al. (2008: 190) seem to indicate that this kind of information instead tends to be added rather than omitted in their English-to-German translations. Further studies are needed to determine 
if any specific kind of information would be more or less likely to be added or omitted crosslinguistically.

Other omissions in the LEGS data concern specifications manifested as source-text elaborations on terms (see example (20)) or additional source-text information on culturespecific items (as in (21)) deemed superfluous by translators.

(20) Attacks mainly by Stuka dive-bombers and by fast $S$-Boote (motor torpedo boats which the British called E-boats) virtually closed the Channel to British convoys. [LEGS; English original]

Anfall av främst Stuka-störtbombare och snabba motortorpedbåtar praktiskt taget stängde Engelska kanalen för de brittiska konvojerna. [Swedish translation]

(21) ... men när man ville klä majstång visade det sig svårt att vid den här årstiden (som dessutom var förskjuten framåt ett par veckor på grund av vår på den tiden omoderna kalender) få tag på blommor och grönt. ('(which besides was moved forward two weeks because of our at that time outdated calendar)') [LEGS; Swedish original] ... however when it came time to decorate the May pole it proved difficult to find enough flowers and greenery at that time of year. [English translation]

As for most omissions, Figures 13 and 14 show that a majority of all downgrades and upgrades involve specifications in all subcorpora. Numbers are lower in these categories (403 downgrades and 228 upgrades).

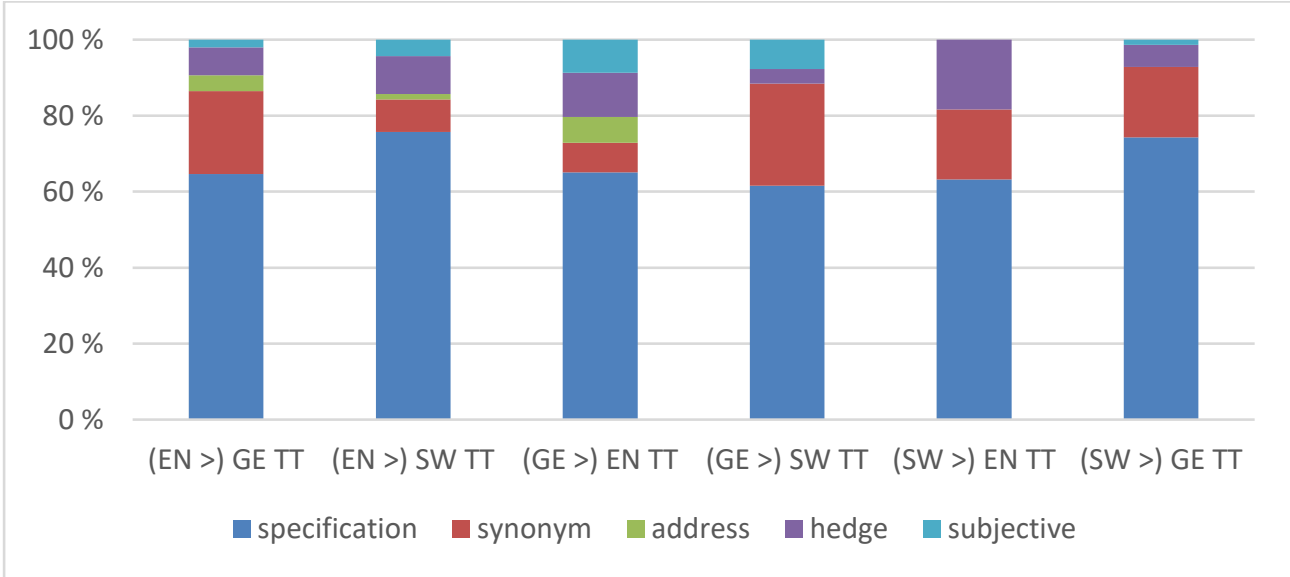

Figure 13. Functional categories of downgraded brackets in translations.

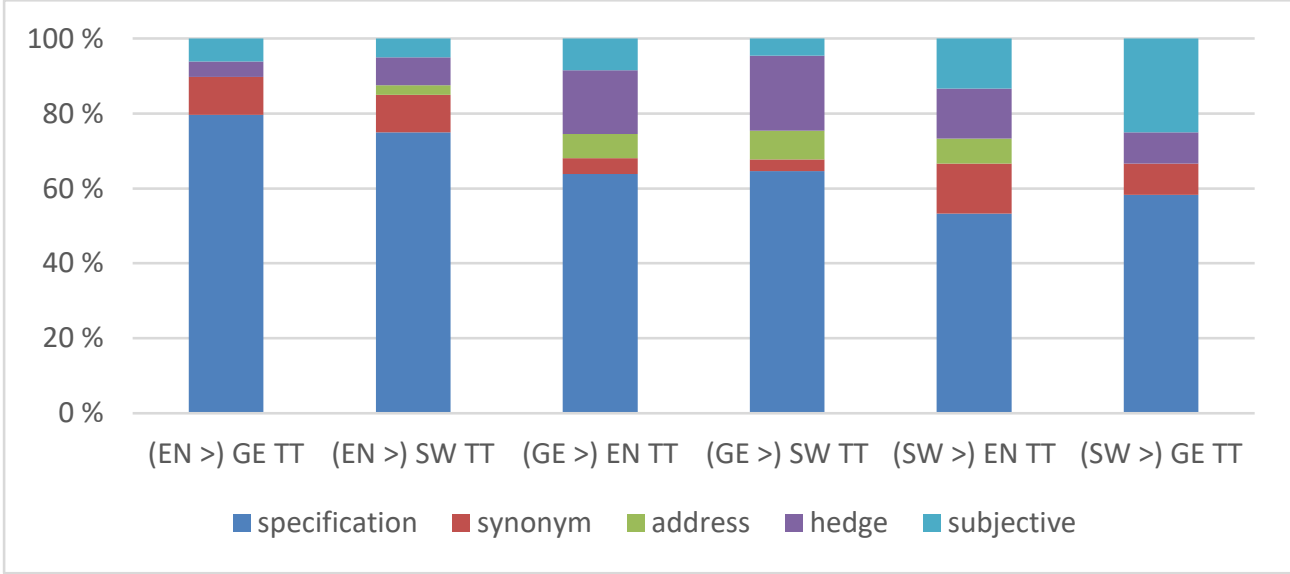

Figure 14. Functional categories of upgraded brackets in translations. 
The choices in individual instances are difficult to explain in relation to the categories of brackets. Specifications account for a majority of all tokens in the three original corpora and this is also the case for both downgrades and upgrades. Individual translators' choices largely seem to determine the usage. For instance, in (22), the English translator chooses to downgrade the German original phrase occurring between dashes, while the Swedish translator, as seen in (23), upgrades the bracketed English original clause by putting it between commas (for further discussions of other punctuation marks as correspondences of brackets, see Section 4.2.3). In (22), the downgrade is introduced in English, the language that is most likely to use noncongruent translations. In (23), on the other hand, the upgrade is introduced in Swedish, which is the language least likely to change punctuation in translation. (For more on punctuation marks in downgrades and upgrades, see next section.)

(22) ... in den digitalen Ordnern, die wir nun Tag für Tag - und immer wieder auch Abend für Abend - durchsehen, ... ('and ever again also evening for evening') [LEGS; German original]

$\ldots$ in the computer folders we mine day after day (and often night after night), ... [English translation]

(23) ... the Clinton administration (which took office in January 1993) ... [LEGS; English original]

... Clintonregeringen, som tillträtt $i$ januari 1993, ... ('the Clinton-administration which [had] taken office') [Swedish translation]

What is noteworthy is that upgrades are the smallest category of change in five out of six translations. As with additions, German-to-Swedish is the exception here, and somewhat unexpectedly, this category is even the largest in this subcorpus. The differences between this subcorpus and the others should nevertheless not be overemphasized, since this particular subcorpus has the lowest number of changes and the differences between the categories are fairly small. The next section will further explore downgrades and upgrades regarding the punctuation marks used as correspondences of brackets.

\subsubsection{Corresponding punctuation marks in downgrades and upgrades}

This section presents a different perspective on translation changes by investigating the punctuation marks that correspond to brackets in downgrades and upgrades. The findings are shown in Figures 15 and 16. As is evident, commas and no punctuation marks ('zero') are the most frequent correspondences. Although dashes are often mentioned as being used in similar functions as brackets, they account for only $10 \%$ of all correspondences in the figures. It is likely that the informal connotations of dashes mentioned in Section 3 (Quirk et al., 1985: 1629; Leech et al., 2009: 245; Crystal, 2015: 158) make them less likely as correspondences of brackets, which, according to Leech et al. (2009: 246), are more typical of "serious written style". 


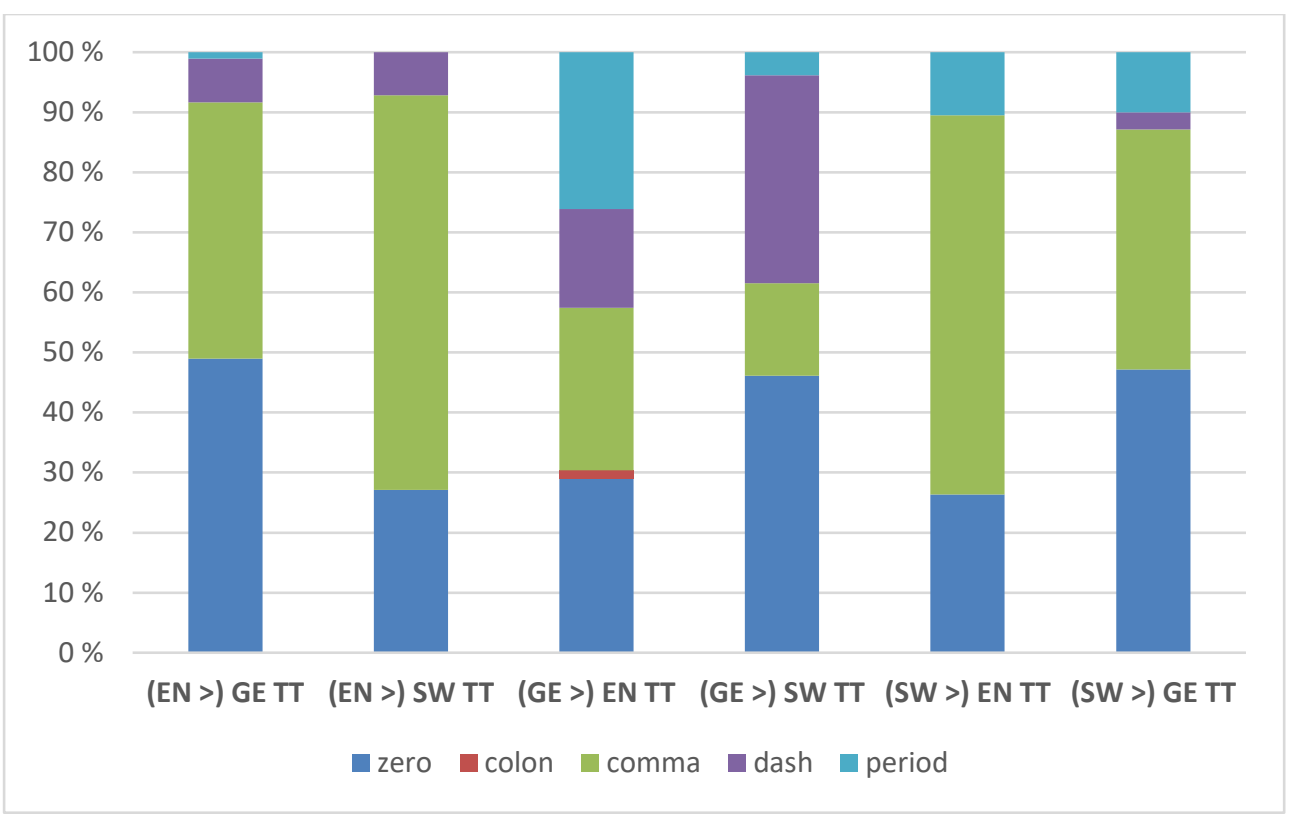

Figure 15. Source-text punctuation in downgrades.

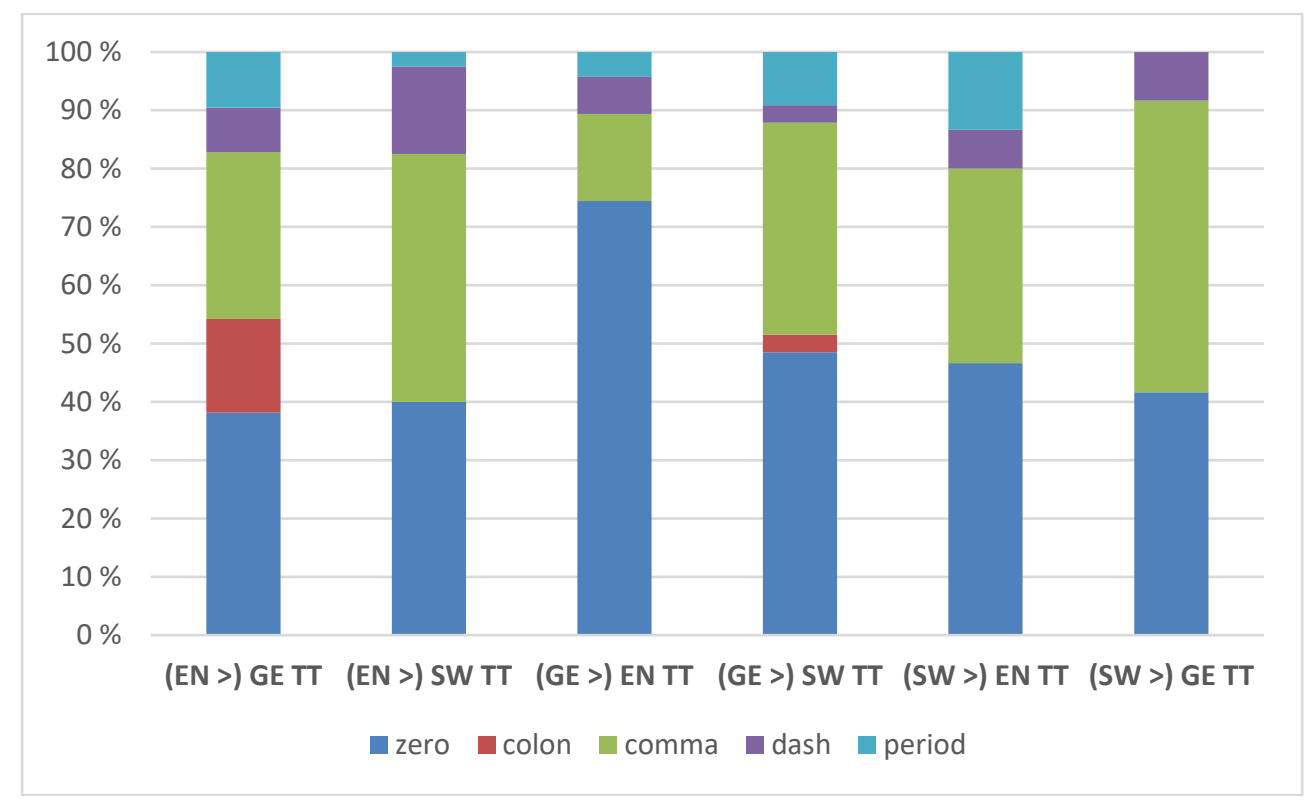

Figure 16. Target-text punctuation in upgrades.

In all translation directions, and this holds for both downgrades and upgrades, either zero punctuation or commas are the most common correspondences. In all subcorpora, these two alternatives account for more than half the instances. In fact, only in the downgrades from German originals do zero punctuation and commas combined not exceed $70 \%$ of the tokens. It should be noted that zero marking and commas were also the most common (non-colon) correspondences of colons in Ström Herold and Levin (forthcoming). It would therefore seem that the frequencies and flexibility of these two options make it more likely for them to be changed from or into brackets in translation. An additional important factor is that commas, like brackets, are correlative marks having similar stylistic values. However, as pointed out by English Style Guide (2016/2019: 12), replacing brackets with commas may have informationstructural consequences regarding the degree of backgroundedness, i.e., bracketed material being more strongly backgrounded than material placed between commas. Translators are more prone to replacing commas with brackets than the other way around. As brackets are considered 
to have a communicative function (Bredel, 2018: 12f.), the introduction of brackets in the translation entails a stronger presence of the writer. However, in translations, readers can usually not distinguish between the authors' and the translators' contributions ${ }^{11}$ (e.g., his parents' visits to the nursery, usually at tea-time on Sundays, could be excruciating occasions $>$ föräldrarnas besök $i$ barnkammaren (vanligtvis vid tedags på söndagarna) kunde vara mycket plågsamma (Sw.) ['usually at tea time on Sundays']). Thus, translations are in this respect different from originals, where it is obvious that all brackets stem from the author.

There are some minor tendencies observable for punctuation changes in downgrades. In some instances, one member of a source-text apposition is put in brackets in the translation (the giant sloth megatherium > das Riesenfaultier (Megatherium) (Ge.)). In others, the target text disallows a certain word order, which leads to obligatory restructuring. For instance, the year in the original English JOHN CHEEVER'S 1961 SHORT STORY "The Angel of the Bridge" must be moved because German does not normally compound years with nouns $(* 1961$ Kurzgeschichte). Instead, the year appears after the title in brackets, as is conventionally done in many languages: JOHN CHEEVERS KURZGESCHICHTE „, Der Engel der Brücke” (1961). In such instances, the change of punctuation mark is a way for translators to solve structural translation problems.

For upgrades, we find similar punctuation changes, though in the opposite direction to downgrades. Thus, a German original introducing an acronym in brackets, von Massenmorden der sowjetischen Geheimpolizei (NKWD) ['mass murders of the Soviet secret police (NKVD)'], was rendered into Swedish as a non-bracketed apposition, den sovjetiska hemliga polisen NKVD:s massmord. Similarly, English translators condense noun phrases by moving the originally bracketed year into premodifying position (wie im Song Going Back von Carole King (1966) ['like in the song'] (Ge.) > think of Carole King's 1966 song Going Back). As shown by Ström Herold and Levin (2019), English noun premodifiers often have different kinds of translation correspondences in German and Swedish, such as postmodifiers or genitives.

Thus, as seen in Sections 4.2.2 and 4.2.3, downgrades and upgrades are rather rare in our material and major generalizations are not easily made. One finding is nevertheless that downgrades and upgrades are often reflections of each other in that a structure that is downgraded into brackets in one text may typically be the result of an upgrade in another. In both downgrades and upgrades, commas and zero punctuation are the most frequent correspondences. The final section shifts focus from punctuation correspondences in downgrades and upgrades to structural changes to bracketed text that is retained in translations.

\subsubsection{Clause building and clause reduction in translations}

The distributions of clauses and phrases in original brackets in Figure 6 above show that there is a stronger preference in German than English and Swedish for putting phrases in brackets. We therefore decided to also compare the distributions of clauses and phrases in translations with their originals. This comparison was restricted to retained brackets, i.e., added, omitted, downgraded and upgraded brackets were not included. In this manner, it is possible to compare the proportions of original clauses and phrases rendered as either clauses or phrases in translations.

Previous studies (Dirdal, 2014; Ström Herold and Levin, 2018, forthcoming) have observed that translations tend to use more elaborate structures than originals, meaning that translators tend to go from phrasal to clausal constructions rather than the other way around. Dirdal (2014: 122) uses the term 'clause building' for those changes that move towards independent main clauses, such as phrases rendered as clauses or non-finite clauses rendered

\footnotetext{
${ }^{11}$ Unless the brackets are explicitly labelled "translator's note".
} 
as finite clauses. The term 'clause reduction' is used to refer to the opposite case. Compared to clause building, clause reduction is usually rare (Dirdal, 2014; Ström Herold and Levin, forthcoming). The tendency towards clause building is also present in our material, but, as will become evident below, only partially. Contrary to Dirdal (2014), we restricted our study to a binary opposition between clausal instances, which consist of verbs in combination with other elements, and phrasal instances, which do not, and instead typically contain noun phrases or prepositional phrases.

In our data, it is only the German originals that trigger significant proportions of clause building. English and Swedish originals, which contain significantly more clauses than German originals (as shown in Figure 6 above), do not yield significant differences between originals and translations. Figure 17 below therefore focuses only on German originals and their translations. The four bars illustrate the distributions of phrases and clauses in the two translations with the blue colour indicating German original phrases and the orange indicating original clauses.

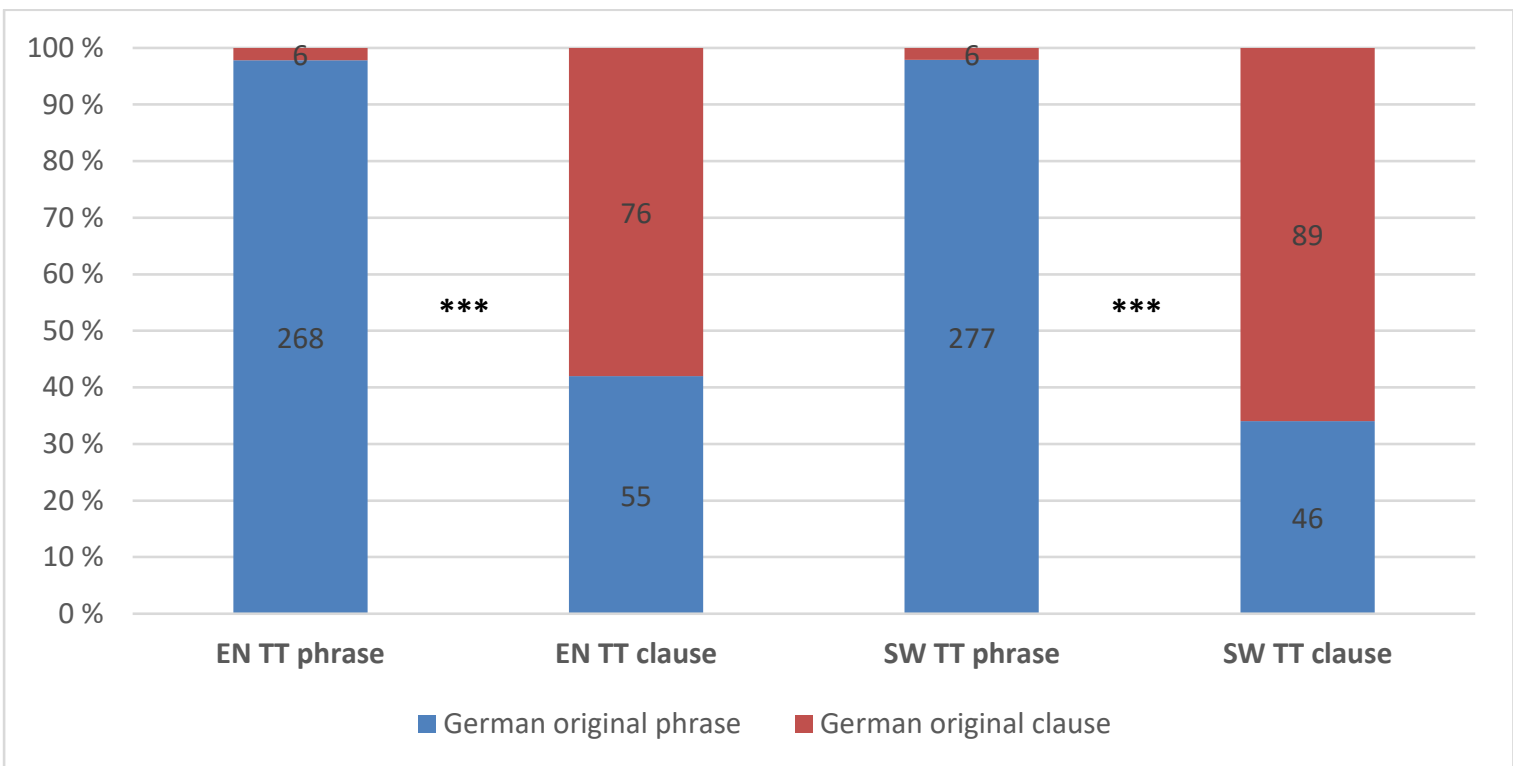

Figure 17. Clause building and clause reduction in translations from German.

The first and third bars in the figure show that German original clauses are very rarely translated into English or Swedish phrases, while phrase-to-phrase translation is the norm. The second and fourth bars show that fairly large proportions of the target-text clauses originate in German source-text phrases. There is a significant likelihood for more phrases to be rendered as clauses than for clauses to be rendered as phrases from these source texts.

Examples (24) and (25) illustrate clause building in the translation of the bracketed text. The German original in (24) explains the term Mikrobiota in a condensed manner using a descriptive noun phrase which, interestingly, is introduced by an equal sign. This explanation is then structurally expanded into an English relative clause in the translation.

(24) Wissenschaftlich korrekt sagt man Mikrobiota (= kleine Leben) oder auch Mikrobiom ... ('= small living beings') [LEGS; German original]

The scientifically correct terms are microbiota (which means "little life") and microbiome, ... [English translation]

The next example, contrary to the short, content-based one above, fulfils an interpersonal function and involves more lexical components expressing a nuanced hedged comment. The 
fragmentary German style of the original is avoided by both translators who instead use full finite clauses by adding subjects, verbs and objects.

(25) Einmal sagte er (möglicherweise sogar in vollem Ernst), der beste Augenblick seiner Präsidentschaft sei gewesen, als ... ('possibly even in all seriousness') [LEGS; German original]

Once he said (and he may have meant it seriously) that the finest moment of his presidency was when ... [English translation]

En gång sa han (och kanske menade han rentav allvar) att det bästa ögonblicket under hans presidenttid var då ... ('and maybe he meant it seriously') [Swedish translation]

Our German original data thus support previous findings on clause building and clause reduction in that translators at least from this source language tend to build clauses rather than reduce clauses to phrases.

\section{Conclusions}

Our investigation into brackets in original texts and translations in nine subcorpora of LEGS has shed light on both similarities and notable differences. In originals, English stands out as the most bracket-friendly language. Brackets are less common in German originals and the rarest in Swedish. However, further studies are needed to establish to what extent these findings are generalizable to other subgenres than those included in our study, such as newspaper text. As for the function of bracketed texts, the languages behave similarly: most brackets are content-oriented as opposed to interpersonal, which suggests that brackets largely have kept their original information-condensing function (cf. Biber and Gray, 2016: 205-206). Still, the relatively large proportions of interpersonal brackets and the differences between our operative and more content-oriented texts indicate that there is an ongoing expansion of functions and frequencies in all three languages.

In translations, most brackets are retained, indicating a fairly high degree of source-text adherence which aligns well with previous translation studies on punctuation. If retention is the most frequently used option, the addition of brackets in translation is the most common non-congruent strategy. Added brackets mostly consist of short synonyms, which suggests that brackets are a frequent unobtrusive means for translators to move the text to the target readers by, e.g., spelling out acronyms or giving additional name variants.

Our results are inconclusive regarding which functional aim is the strongest: do translations usually contain more brackets than their originals because translators strive to bring the text closer to the target-text readers or do translators aim for the target-text norms? Further studies are certainly warranted, though an interesting finding is that the most marked differences between original and translations appears with Swedish originals, where the two tendencies would promote increased use of brackets.

The present findings are similar to those found for colons (Ström Herold and Levin, forthcoming) in that English translators are more "daring", using the most non-congruent translations. Swedish translators introduce the least and this difference may be connected to differences in language status and power relations. Another finding already indicated in previous studies relates to the nominal style in German (Carlsson, 2004). In view of this, it is not surprising that English translators often build clauses (cf. Dirdal, 2014) from phrases in translations from German. The tendency for clause building is nevertheless strong enough for Swedish translators to also build clauses in translations from German, in spite of their generally more cautious approach to the introduction of changes. 
By using a bidirectional trilingual translation corpus, we have, at least to some extent, been able to tease apart specific language preferences and translation-induced changes. However, as with most studies, the present study calls for further investigations. Will similar results be found with different language pairs, genres and punctuation marks? The competition between translation-specific and language-specific tendencies that may or may not work against each other will certainly constitute a fruitful field for future work.

\section{References}

Baker, M. 1993. Corpus Linguistics and Translation Studies: Implications and Applications. In Text and Technology: In honour of John Sinclair, M. Baker, G. Francis and E. Tognini-Bonelli (eds), 233-250. Amsterdam: John Benjamins.

Baker, M. 1996. Corpus-based Translation Studies: The Challenges that Lie Ahead. In Terminology, LSP and Translation: Studies in Language Engineering in Honour of Juan C. Sager, H. Somers (ed.), 175-186. Amsterdam: John Benjamins.

Baumgarten, N., Meyer, B. and Özçetin, D. 2008. Explicitness in translation and interpreting: A critical review and some empirical evidence (of an elusive concept). Across Languages and Cultures 9(2): 177-203.

Becher, V. 2011. Von der Hypotaxe zur Parataxe: Ein Wandel im Ausdruck von Konzessivität in neueren populärwissenschaftlichen Texten. In Satzverknüpfungen. Zur Interaktion von Form, Bedeutung und Diskursfunktion, E. Breindl, Gi. Ferraresi and A. Volodina (eds), 181-209. Berlin: de Gruyter.

Biber, D. and Gray, B. 2016. Grammatical Complexity in Academic English. Linguistic Change in Writing. Cambridge: Cambridge University Press.

Bisiada, M. 2013. Changing Conventions in German Causal Clause Complexes. A Diachronic Corpus Study of Translated and Non-translated Business Articles. Languages in Contrast 13(1): 1-27.

Bredel, U. 2018. Das Interpunktionssystem des Deutschen. Studia Neophilologica 90(1): 7-23.

Carlsson, M. 2004. Deutsch und Schwedisch im Kontrast: Zur Distribution nominaler und verbaler Ausdrucksweise in Zeitungstexten. PhD dissertation, Gothenburg University.

Crystal, D. 2015. Making a Point: the Pernickety Story of English Punctuation. London: Profile Books.

Dirdal, H. 2014. Individual Variation between Translators in the Use of Clause Building and Clause Reduction. In Corpus-based Studies in Contrastive Linguistics, S.O. Ebeling, A. Grønn, K.R. Hauge and D. Santos (eds), Oslo Studies in Language 6 (1): 119-142.

Duden. Band 9. Das Wörterbuch der sprachlichen Zweifelsfälle. Richtiges und gutes Deutsch. 8th ed. 2016. Berlin: Dudenverlag.

English Style Guide. A handbook for authors and translators in the European Commission. 2016/2019. European Union.

Englund Dimitrova, B. 2014. Till punkt och pricka? Översättarstil, normer och interpunktion vid översättning från bulgariska till svenska. Slovo. Journal of Slavic Languages, Literatures and Cultures 55: 77-99.

Frankenberg-Garcia, A. 2019. A Corpus Study of Splitting and Joining Sentences in Translation. Corpora 14(1): 1-30.

Gustafsson, R. 2013. Att översätta kolon. En undersökning av hur skiljetecknet kolon överförs från franska till svenska i skönlitterära översättningar. MA thesis. Gothenburg University.

House, J. 1997. Translation Quality Assessment: A Model Revisited. Gunter Narr Verlag: Tübingen.

House, J. 2011. Using Translation and Parallel Text Corpora to Investigate the Influence of Global English on Textual Norms in Other Languages. In Corpus-based translation studies, A. Kruger, K. Wallmach and J. Munday (eds), 187-208. London: Bloomsbury.

Index Translationum. UNESCO. N.d. Available at: http://www.unesco.org/xtrans/ [Last accessed 4 June 2021]

Ingo, R. 2007. Konsten att översätta. Översättandets praktik och didaktik. Lund: Studentlitteratur. 
Kranich, S. 2011. To Hedge or Not to Hedge: The Use of Epistemic Modal Expressions in Popular Science in English Texts, English-German Translations, and German Original Texts. Text \& Talk 31: 77-99.

Leech, G., Hundt, M., Mair, C. and Smith, N. 2009. Change in Contemporary English. A Grammatical Study. Cambridge: Cambridge University Press.

Nádvorníková, O. 2020. The Use of English, Czech and French Punctuation Marks in Reference, Parallel and Comparable Web Corpora: A Question of Methodology. Linguistica Pragensia 30(1): 30-50.

Quirk, R., Greenbaum, S., Leech, G. and Svartvik, J. 1985. A Comprehensive Grammar of the English Language. London: Longman.

Shiyab, Said M. 2017. Translation: Concepts and Critical Issues. Antwerp: Garant Publishers.

Ström Herold, J. and Levin, M. 2018. English supplementive ing-clauses and their German and Swedish correspondences. In Corpora et Comparatio Linguarum: Textual and Contextual Perspectives, S.O. Ebeling and H. Hasselgård (eds.), Bergen Language and Linguistics Studies 9(1), 115-138.

Ström Herold, J. and Levin, M. 2019. The Obama Presidency, the Macintosh Keyboard and the Norway Fiasco: English Proper Noun Modifiers in German and Swedish Contrast. English Language and Linguistics 23(4): 827-854.

Ström Herold, J. and Levin, M. Forthcoming. The Colon in English, German and Swedish: A contrastive corpus-based study. Comparative Punctuation. Linguistik - Impulse \& Tendenzen. Berlin, New York: Walter de Gruyter.

Wollin, L. 2018. Punctuation: Providing the Setting for Translation? Studia Neophilologica 90(1): 3749.

Authors' addresses

Magnus Levin / Jenny Ström Herold

Linnaeus University

Department of Languages

SE-351 95 Växjö

Sweden

magnus.levin@1nu.se / jenny.strom.herold@1nu.se 